\title{
Gender bias and stereotypes in Australian, Singaporean and Turkish mathematics textbooks
}

\author{
Lütfi İncikab1 \\ Kastamonu University, Faculty of Education, Kastamonu, Turkey, lincikabi@kastamonu.edu.tr \\ Fadime Ulusoy \\ Kastamonu University, Faculty of Education, Kastamonu, Turkey, fadimebayik@gmail.com
}

\begin{abstract}
This cross-national study aimed to examine gender bias and stereotypes in Australian, Singaporean and Turkish elementary mathematics textbooks. Content analysis approach was used to provide descriptive statistics about the number of male/female and gender-neutral characters in the textbooks. Findings indicated that total frequencies in textbook contents including no gender bias was under nine percent in all textbooks. No gender bias was more prevalent across the grade levels in Australian textbooks. Singaporean mathematics textbooks had more discrepancy between the percentages of boys' and girls' representations than the representations in Turkish and Australian textbooks. In terms of math-gender stereotypes, all textbooks across grade levels were generally neutral. Social roles in mathematics textbooks across the countries had more variation for men than women with higher frequencies in all countries. The masculine roles were commonly attributed to men with more technical and intellectual tendency while domestic roles were ascribed to females.
\end{abstract}

Keywords: Content analysis, Gender representation, Mathematics textbooks, Social roles, Stereotypes,

\section{Avustralya, Singapur ve Türkiye'de matematik kitaplarındaki cinsiyet eğilimleri ve basmakalıplar}

ÖZ Bu çalışmanın amacı, Singapur, Avustralya ve Türkiye'nin ilköğretim matematik kitaplarındaki cinsiyet eğilimlerini ve kullanılan basmakalıpların neler olduğunu incelemektir. Ders kitaplarında erkek/kadın ve nötr cinsiyet karakterlerinin sayısı ve özellikleri hakkında tanımlayıcı istatistikler sağlamak için içerik analizi yaklaşımı kullanılmıştır. Bulgular, cinsiyet ile ilgili basmakalıplar içermeyen ders kitabı içeriklerinin tüm ders kitapları için yüzde dokuzun altında olduğunu göstermiştir. Sınıf düzeyleri boyunca, Avustralya ders kitaplarında cinsiyet yanlılığının daha az olduğu tespit edilmiştir. Singapur matematik ders kitaplarının, erkek ve kız çocuk temsil yüzdeleri arasındaki farkın, Türk ve Avustralya ders kitaplarındaki temsillere oranla daha fazla olduğu görülmüştür. Matematik-cinsiyet basmakalıpları açısından, sınıf seviyelerindeki tüm ders kitaplarının genellikle tarafsız bir yaklaşım içerdiği görülmüştür. Ülkeler genelindeki ders kitaplarındaki toplumsal roller, erkekler için tüm ülkelerde kadınlara atanan rollere kıyasla daha fazla çeșitlilik göstermiștir. Kitaplarda, daha teknik ve entelektüel içerikli roller erkekler için tasvir edilirken, domestik roller yoğunlukla kadınlar için tasvir edilmiştir.

Anahtar Basmakalıplar, Cinsiyet temsili, İçerik analizi, Matematik ders kitapları, Toplumsal roller

Kelimeler: 


\section{INTRODUCTION}

From the standpoint of educational equity, boys and girls should have the same access to all educational opportunities (Bae, Choy, Geddes, Sable, \& Snyder, 2000). However, the classroom can paradoxically become a place that support the formation of gender bias and stereotypes that stress boys are superior and more competent than girls (Blumberg, 2007; Chisamya, Dejaeghere, Kendall, \& Khan, 2012). With the influence of such perceptions, girls have limited access to educational opportunities at schools when compared to boys (Murphy \& Gipps, 1996; Zhang, Kao, \& Hannum, 2007). As an important element in education, textbooks should have the contents that should support the individuals in terms of cognitive, psychological and social aspects (Biemmi, 2015). Balanced gender representation in textbooks helps to achieve equality between girls and boys at school (Baldwin \& Baldwin, 1992; Biemmi, 2015; Blumberg, 2008). At this point, it can be expected that the studies on gender equity in the contents of textbooks are even more important because biased textbook contents limit females in many ways such as career choices and self-image (Britton \& Lumpkin, 1977; Wu, Widjaja, \& Li, 2016). Yet, compared to other school-specific factors concerning gender inequality, gender bias in textbooks is a less-studied educational issue in a world where 72,000,000 children still have no access to schooling (Fan, Zhu, \& Miao, 2013; Islam \& Asadullah, 2018). Thus, "gender bias in textbooks is: (1) an important, (2) nearuniversal, (3) remarkably uniform, (4) quite persistent but (5) virtually invisible obstacle on the road to gender equality in education" (Blumberg, 2008, p. 345).

Among school subjects, mathematics has a long history of being driven by textbooks and curriculum materials that teachers use to teach mathematics topics (Remillard, 2005). Today, the mathematics textbook remains as a major classroom resource for learning and teaching mathematics (e.g., Nicol \& Crespo, 2006). According to the traditional view, mathematical knowledge is often thought as culturefree and purely rational (Tang, Chen, \& Zhang, 2010). However, sociological studies note that "knowledge" cannot be oversimplified as subject knowledge because it is also shaped by social practice. Although mathematics has a universal symbolic language, mathematics textbooks are designed by people selectively and include intense cultural and social information (Shi, 2004; Tang et al., 2010). Thus, mathematics textbooks provide explicit (e.g., information contains mathematical knowledge that students learn from textbooks) and implicit information (e.g., social and cultural messages) for the learners and teachers (Pepin \& Haggarty, 2001; Wu, Widjaja, \& Li, 2016). Furthermore, students spend considerable time using mathematics textbooks at school or at home to do the assigned homework, and teachers from primary to $t$ make use of mathematics textbooks to understand the curriculum objectives and to shape their pedagogical practices from primary to tertiary level (e.g., Zakka, Oluyemi, \& Twaki, 2015). Thus, mathematics textbooks play a significant role in conveying both mathematical knowledge and cultural/social values.

Design and quality of mathematics textbooks are also an important factor in students' mathematics attainment both cognitively and affectively. Traditionally, there is an impression that males are more talented or successful in learning mathematics. Based on this assumption, the math-gender stereotype stresses that boys are superior and more competent than their female counterparts in mathematics (Franceschini, Galli, Chiesi, \& Primi, 2014; Passolunghi, Rueda-Ferreira, \& Tomasetto, 2014; Steffens, Jelenec, \& Noack, 2010). Mathematics textbooks can support this impression implicitly or explicitly with their language, presentation of content and images (Tang et al., 2010). As a consequence, mathgender stereotypes in textbooks considerably influence female's mathematics performance (Quinn \& Spencer, 2001; Tine \& Gotlieb, 2013), daily-life (Bieg, Goetz, Walter, \& Hall, 2015), self-esteem and self-assessment of mathematical success (Correll, 2001; Lindberg, Linkersdörfer, Ehm, Hasselhorn, \& Lonnemann, 2013; Martinot \& Désert, 2007), and their future math-related career choice negatively (Good, Rattan, \& Dweck, 2012; Schmader, Johns, \& Barquissau, 2004). Obviously, math-gender 
stereotypes in mathematics textbooks are not the sole cause of the difference between female and male learners' mathematics performance, attitude and achievement level. However, Zhang and Zhou (2008) noted that gender imbalance in textbooks has an unfavorable effect on learners, especially on girls, in the long term. As time passes students unconsciously develop perspectives on gender-related values that males and females play in textbooks, which shapes their behaviors in society. Hence, considering mathgender stereotypes, it is very important to examine the gender equity and stereotypes in mathematics textbooks.

Many researchers have noted that school mathematics courses serve as an important filter for career outcomes, preventing unsuccessful mathematics students from gaining high status in the future (e.g., Shapka, Domene, \& Keating, 2006; Sherman, 1982). Moreover, gender representation and genderrelated stereotypes in mathematics textbooks are also causes of low achievement in mathematics and may, in turn, result in pursuing a lower-prestige career (e.g., Plante, Theoret, \& Favreau, 2009). In this sense, although gender difference in attitude towards mathematics and achievement have decreased considerably over thirty years (Hanna, 2000; Wu et al., 2016), recent studies indicate that there is still a greater male dominance over women in the contents of most textbooks in the western and non-western societies (Islam \& Asadullah, 2018; Ullah, Abdullah, Ahmad, \& Ali, 2017). According to Fan et al. (2013), although providing balanced representation of gender in mathematics textbooks is crucial for both the development and the use of textbooks effectively, there are few textbook analyses related to gender and equity issues. They also stated that "these issues are still worth reasonable attention, especially for textbook developers and policy makers (p. 639)". Similarly, some researchers propose that gender bias in textbooks and differentiation in teachers' instructional approach have not been given adequate attention by scholars (Blumberg, 2007; Ullah et al., 2017). Yet, it is one of the crucial obstacles "on the road to gender equality" (Blumberg, 2008, p. 346). On the other hand, the majority of existing studies that were conducted on Italian (Muzzatti \& Agnoli, 2007; Passolunghi et al., 2014), German (Steffens et al., 2010), French (Martinot \& Desert, 2007) and American textbooks (Heyman \& Legare, 2004; Kurtz-Costes, Rowley, Harris-Britt, \& Woods, 2008) demonstrated that children's math-gender stereotypes begin at senior elementary level (age eight or older). Thus, math-gender stereotypes have been evaluated as a potential threat to the development of female students studying at the elementary school (Zhao, Zhang, Alterman, Zhang, \& Yu, 2018). For this reason, we focused on gender equity and stereotypes in elementary-level mathematics textbooks. Particularly, the current study aims to investigate the inclusion of gender bias in elementary school mathematics textbooks from Turkey, Singapore and Australia. The research questions are as follows:

How is the distribution of the gender existence (inclusion) in elementary school mathematics textbooks from Australia, Singapore and Turkey?

How do textbooks perpetuate stereotypes regarding mathematics ability and social roles?

\section{Studies on Gender Bias in Textbooks}

Gender stereotyping in learning material is not a newly discovered field of study. Earlier studies conducted by second feminists in the 1970s extensively studied and debated gender representation in school textbooks across the world (Britton \& Lumpkin, 1977). Previous studies found that textbooks heavily included gender stereotyping (Cincotta, 1978; Crabb \& Bielawski, 1994; Peterson \& Lach, $1990)$ in which males had social and intellectual roles, and women were depicted as more emotional and in mainly domestic roles (Hartman \& Judd, 1978). In the past ten years or so, researchers have shown interest in gender bias in learning materials again (e.g., Blumberg, 2007; Wu et al., 2016). The main message of these studies is evident: gender inequality in textbooks influences the development of learners' self-esteems, motivation and attitudes towards the sexes and school subjects.

This section presents an overview of recent empirical studies in order to gain a perspective on gender bias in textbooks in different countries. In a cross-national study, in order to identify gender stereotypes, Islam and Asadullah (2018) conducted a comparative content analysis of English textbooks in four 
countries in South and South-East Asia which differ in the rate of female schooling (Malaysia, Indonesia, Pakistan and Bangladesh). They found that female characters in textbooks were underrepresented. While occupations attributed to females were mostly traditional, domestic and less prestigious (e.g., housewife, mother, secretary), males were depicted as powerful, prestigious and wealthy in textbooks. For the authors, elimination of stereotypes in textbooks and classroom practices is a necessary action to ensure gender equality. In another recent study, Ullah et al. (2017) investigated stereotypical representation of men's and women's activities and social roles in mathematics textbooks used in Azad Jammu and Kashmir. They found out that mathematics textbooks in primary education included gender stereotypes. They concluded that boys/men were portrayed in the public domain (e.g., doing in business, driving, etc.) while women/girls were presented in private domain of home with domestic roles (e.g., cooking, caring babies, helping children with homework, etc.).

On the other hand, some studies revealed that there are differences in representation of gender in textbooks in some countries (Pakistan, Iran and Hong Kong) (Chanzanagh, Esmaeelzadeh, \& Zarsazkar, 2011). They revealed that although there were more male characters than female characters in English textbooks in Pakistan and Iran, there was equal representation of girls and boys in textbooks in Hong Kong. Wu et al. (2016) conducted another comparative study between Chinese and Australian mathematics textbooks to investigate gender representation. Their findings have similarities with the results of the previous research on Chinese textbooks (Tang et al., 2010; Zhang \& Zhou, 2008). According to $\mathrm{Wu}$ et al. (2016), while there are more male characters in Chine textbooks in three different grades, this dominancy is seen only in Australian sixth grade textbooks. Chinese textbooks include more gender stereotypical statements and pictures, whilst Australian textbooks are more gender-equal. For example, while girls are presented in some masculine roles (e.g., carpenter, newspaper reader, basketball player) and males are illustrated in feminine social roles such as cleaner in Australian textbooks, broader and higher social-status roles that require technical and intellectual abilities are attributed to males in Chinese textbooks (Wu et al., 2016). These results indicate that even though some countries have gender equality in the presentation of learning materials, unbalanced gender representation is still a matter for many countries.

\section{The Selection of Countries}

Spencer, Steele and Quinn (1999) have presented that negative math-gender stereotypes could be the reason of persistent poor performance of female students in standardized tests of mathematics. Similarly, a recent meta-analysis indicates that stereotypes negatively influence female students' mathematics performance (Doyle \& Voyer, 2016). From this point of view, in the selection of the countries from which we chose mathematics textbooks, we examined mathematics mean score of all countries in PISA 2015 and decided to select three countries with an average mathematics test score in PISA 2015, which was (a) above the OECD average, (b) below the OECD average, and (c) had the same average as the OECD average, respectively. Furthermore, some researchers used Gender Parity Index in the selection of countries. Similarly, in the current study, we have also focused on the scores of Global Gender Gap Index and literacy rate where the countries vary considerably. Global Gender Gap Index has been calculated by the World Economic Forum [WEF] by examining datasets produced by WEF, UNESCO Institute of Statistics, and the OECD in terms of their economic participation and opportunity, educational attainment, health and survival, and political empowerment. The highest possible score is 1 (equality) while the lowest one is 0 (inequality). According to Global Gender Gap Index 2017, the highest score was calculated as .878 for Iceland, and the lowest score was calculated as .516 for Yemen among 144 countries.

We decided to examine gender representation and stereotypes in Singaporean, Australian and Turkish mathematics textbooks (see Table 1). Australia had a higher score than Singapore and Turkey in terms of gender equality. Similar scores were also observed in the literacy rate of females and males. However, related literature reveals that there has been limited number of studies on gender representation in Turkish (English as a Foreign Language) textbooks (Bag \& Bayyurt, 2015) or Singaporean (picture) books (Luyt, Lee, \& Young, 2011). Similarly, there are few studies on gender representation in 
Australian mathematics textbooks (e.g., Wu et al., 2016). Therefore, we think that the current crossnational study may provide opportunities for policy makers, curriculum developers, and educators to develop a deeper understanding of gender stereotypes and equity in mathematics learning materials of different countries.

Table 1.

Some characteristics of countries

\begin{tabular}{lcccccc}
\hline \multirow{2}{*}{ Country } & \multicolumn{2}{c}{ Global Gender Gap Index 2017 } & 2015 PISA Average Math Test Score* & \multicolumn{2}{c}{ Literacy rate } \\
\cline { 2 - 7 } & Rank & Score & Rank & Score & Female & Male \\
\hline Australia & 35 & .731 & 25 & 497 & 99 & 99 \\
Singapore & 65 & .702 & 1 & 564 & 95 & 99 \\
Turkey & 131 & .625 & 57 & 420 & 93 & 99 \\
\hline
\end{tabular}

*Rank represents the arrangement of each country among 74 countries held PISA 2015. The highest score in 2015 PISA Math Test was 564 and the least score was 328 .

\section{METHODOLOGY}

Being qualitative in nature, the current study utilized document analysis method to examine gender elements in mathematics textbooks. Document analysis includes recording the existing records and documents related to the subject to be investigated and then coding these documents according to a certain norm or system (Cohen, Manion, \& Morrison, 1994).

\section{Selection of Textbooks}

In this study, the textbooks were selected based on purposive sampling strategy. Table 2 gives the information about the selected textbooks. Turkey and Singapore utilize standardized textbooks in their classrooms while mainstream teaching materials are used in Australia. In Turkey, textbooks are compulsory in primary and secondary education. Adoption of a textbook for instruction depends on the approval of Ministry of National Education. Turkish textbooks are evaluated on the basis of four basic dimensions: (1) the conformity to the instructions of MoNE, (2) scientific competence, (3) the level of achievement of instructional objectives, and (4) quality of visual and content design. Similarly, Singaporean textbooks need to be approved by Singapore's MoNE before they can be adopted.

Table 2 .

List of textbooks used in the study

\begin{tabular}{llcl}
\hline Country & Textbook Series & Year Published & Publisher \\
\hline \multirow{5}{*}{ Australia } & Mathematics for Australia 5 & 2014 & Haese Mathematics \\
& Mathematics for Australia 6 & 2015 & Haese Mathematics \\
& Mathematics for Australia 7 & 2015 & Haese Mathematics \\
& Mathematics for Australia 8 & 2014 & Haese Mathematics \\
\hline \multirow{5}{*}{ Singapore } & New Syllabus Primary Mathematics 5A & 2017 & Shinglee \\
& New Syllabus Primary Mathematics 5B & 2017 & Shinglee \\
& New Syllabus Primary Mathematics 6A & 2013 & Shinglee \\
& New Syllabus Primary Mathematics 6B & 2013 & Shinglee \\
& New Elementary Mathematics Syllabus D 1 & 2014 & Marshall Cavendish Edu. \\
& New Elementary Mathematics Syllabus D 2 & 2013 & Marshall Cavendish Edu. \\
\hline \multirow{5}{*}{ Turkey } & Middle School Mathematics Course Book 5 & 2017 & MEB Publishing \\
& Middle School Mathematics 6 & 2015 & Mega Publishing \\
& Middle School Mathematics Course Book 7 & 2017 & Gizem Publishing \\
& Middle School Mathematics Course Book 8 & 2017 & Öğ̈̈ Publishing \\
\hline
\end{tabular}


As a representative of math textbooks in Singapore, the textbook series, New Syllabus D Mathematics, was selected for the study. In the Australian case, different states develop different curriculum standards. These curriculum standards can be referenced by authors who want to write textbooks for the Australian curriculum. Therefore, mainstream textbooks are widely used in Australia. Although the publication date of the textbooks is 2013 and later, the approval of their usage as a textbook is still continuing by the related institutions (Ministry of Education Singapore, 2019).

\section{Unit of Analysis in Textbooks}

In this study, we used visual elements and scenario/problems as the unit of analysis in the analysis of the data. If a scenario/problem includes visual elements we evaluated scenario/problem and visual elements separately in terms of gender inclusion. In this regard, Table 3 shows the distribution (f) of the contents to be analyzed in textbooks. According to Table 3, a total of 3008 content items were (1281 visual elements and 1727 problem scenarios) investigated in order to determine the gender inclusion in the textbooks. Australian textbooks provided more gender-related contents than Singaporean textbooks while Turkish textbooks had the least amount of content regarding the gender issues to be examined in the current study.

Table 3.

Content distribution across the textbooks $(f)$

\begin{tabular}{lccc}
\hline Textbooks & Visual Elements & Scenario/Problem & Total \\
\hline Australia & 691 & 793 & 1484 \\
Grade 5 & 88 & 201 & 289 \\
Grade 6 & 210 & 202 & 412 \\
Grade 7 & 194 & 148 & 342 \\
Grade 8 & 199 & 242 & 441 \\
\hline Singapore & 267 & 610 & 877 \\
Grade 5 & 7 & 83 & 90 \\
Grade 6 & 159 & 84 & 243 \\
Grade 7 & 54 & 261 & 315 \\
Grade 8 & 47 & 182 & 229 \\
\hline Turkey & 323 & 324 & 647 \\
Grade 5 & 153 & 98 & 251 \\
Grade 6 & 61 & 99 & 160 \\
Grade 7 & 64 & 80 & 144 \\
Grade 8 & 45 & 47 & 92 \\
\hline Total & 1281 & 1727 & 3008 \\
\hline
\end{tabular}

\section{Coding Procedures}

To respond to the first research question, images (photos, pictures etc.) and problem-solving contexts (focusing on names and nouns) were analyzed in terms of gender inclusion. Gender dominancy in the items has been determined as follows. Between the both genders in an image, the one who has the largest image or the leading role in a specific situation was coded as the dominant gender. In the case where both genders are evident in a content and no classification was reached using the criteria above, counts (frequencies) of the genders are used to find out the gender dominancy. Contents having both gender but not the criteria above, were coded as "no gender bias".

The targeted math-stereotype in the current study was "difficulty of females in learning/doing mathematics". Doing mathematics or carrying out mathematical procedures is evaluated by analyzing the situations. Each gender-related situation was coded as counter-stereotype (CS), supporting stereotype (SS) or neutral (N). A gender-related content is coded as CS if it includes a female student doing mathematics (for example, it pictures a female solving a problem on the board or a female student playing problem-solver role in a story problem) or coded as SS in an opposite situation. A content that does not highlight any gender's engagement in mathematics is coded as neutral. Stereotypes regarding social roles are analyzed by inspecting social roles or occupations in textbooks provided for each gender. 
In order to check inter-rater reliability, three coders who are proficient in both English and Turkish languages and had experiences with textbooks participated in the coding process of the textbooks. Due to the multiplicity of data to be encoded, at the beginning, 442 content items in the Australian eighth grade textbook were independently coded by three coders. The inter-rater reliability of the first codes was calculated as $82.7 \%$ according to Fleiss' Kappa formula. Then, coders met and discussed the items causing disagreement and reached an agreement on each disputed item. Then, the same content was also coded by an expert (in the field of math education). The interrater agreement rate between the coders and the expert were calculated as $92.7 \%$ according to Cohen's Kappa formula. Discussions on the causes of disagreement resulted in a consensus. Then, the content items $(f=315)$ of the Singaporean seventh grade book were coded by three coders. The reliability coefficient in this coding was calculated as $97 \%$. This ratio is defined as a high percentage of compliance. The items causing disagreement were discussed with the expert, and a decision was reached. The remaining content items were shared among coders, and coders worked independently. Finally, coded data were examined both qualitatively and quantitatively in order to identify the similarities and differences among the mathematics textbooks of three countries in terms of gender issues.

\section{FINDINGS}

\section{Gender Inclusion and Dominancy}

Table 4 (see Appendix 1) shows the gender inclusion in the textbooks across the grade levels. In general, textbooks from all countries provided more contents that have male characteristics while contents with no gender bias are less than $9.5 \%$ of the all gender-related contents. As seen in Figure 1, male dominant items in textbooks were in the form of explanations for rules or facts (1a), providing examples (1b) or story problems (1c).

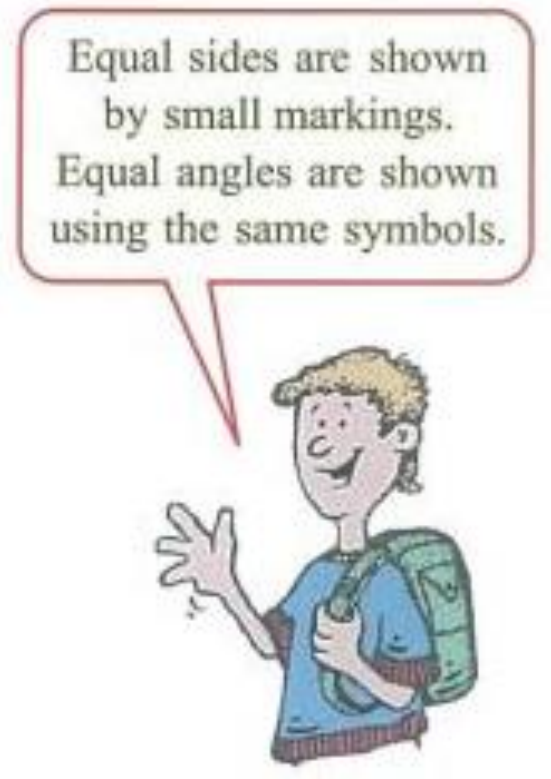

(1a) (A6, p.75)

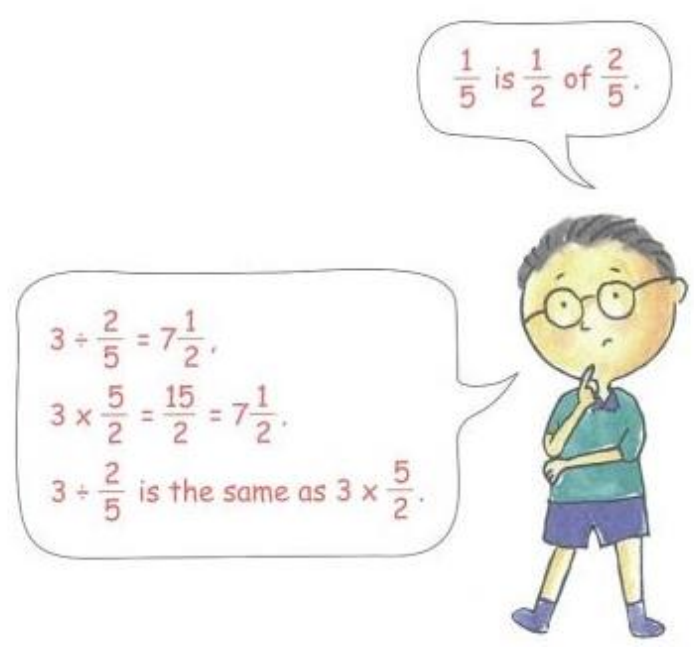

(1b) (S6, p.67)

John accidentally enters $98 \times 3429$ into his calculator instead of $98 \times 3428$. How much should he subtract in order to get the correct answer?

(1c) (S7, p.29)

Figure 1. Samples for male dominant items 
Table 4.

Percentage distribution of gender inclusion in textbooks

\begin{tabular}{|c|c|c|c|c|c|c|c|}
\hline Textbooks & \multicolumn{2}{|c|}{ Dominancy } & $5^{\text {th }}$ & $6^{\text {th }}$ & $7^{\text {th }}$ & $8^{\text {th }}$ & Total \\
\hline \multirow{5}{*}{ Australian textbooks } & Only male & & 42.9 & 45.4 & 52.2 & 49.2 & 47.6 \\
\hline & Only Female & & 42.2 & 36.9 & 36.4 & 39.9 & 38.7 \\
\hline & \multirow{3}{*}{ Mixed Gender } & Male dominant & 4.9 & 4.1 & 3.8 & 2.7 & 3.8 \\
\hline & & Female dominant & 4.9 & 4.1 & 2.9 & 2.0 & 3.4 \\
\hline & & No gender bias & 4.9 & 9.5 & 4.7 & 6.1 & 6.5 \\
\hline \multirow{5}{*}{ Singaporean textbooks } & Only male & & 41.1 & 57.2 & 81.6 & 69.4 & 67.5 \\
\hline & Only Female & & 44.4 & 33.7 & 10.5 & 16.6 & 22.0 \\
\hline & \multirow{3}{*}{ Mixed Gender } & Male dominant & 4.4 & 1.6 & 3.5 & 3.1 & 3.0 \\
\hline & & Female dominant & 1.1 & 0.8 & 1.0 & 1.7 & 1.1 \\
\hline & & No gender bias & 8.9 & 6.6 & 3.5 & 9.2 & 6.4 \\
\hline \multirow{5}{*}{ Turkish textbooks } & Only male & & 48.4 & 68.8 & 38.2 & 40.0 & 50.5 \\
\hline & Only Female & & 40.0 & 20.0 & 29.9 & 26.7 & 31.2 \\
\hline & \multirow{3}{*}{ Mixed Gender } & Male dominant & 1.2 & 2.5 & 8.5 & 12.8 & 4.7 \\
\hline & & Female dominant & 3.2 & 1.3 & 6.4 & 8.1 & 4.1 \\
\hline & & No gender bias & 7.2 & 7.5 & 15.6 & 9.3 & 9.4 \\
\hline
\end{tabular}

In the case of Australian mathematics textbooks, male appearance is more prevalent across the grade levels, especially at the 7 th grade level $(52.2 \%)$. According to Table 4, female-related items were at highest level with $42.2 \%$ in the 5 th grade textbooks, and their inclusion decreased in textbooks until the 8th grade level. Among the content with both genders, no gender bias was more prevalent across the grade levels in Australian math textbooks. Singaporean 5th grade textbook is the only one that includes more female contents than male-related ones; however, the other Singaporean textbooks included more male-related items, especially at the 7th and 8th grade. Similar to the Australian textbooks, items including both genders, most of the time, showed no gender bias across the grade levels in Singaporean math textbooks. Turkish math textbooks included more male-related items than female-related ones while this gap was at the largest level at the 6th grade level. For most of the items including both genders, Turkish math textbooks also showed no gender bias across the grade levels.

\section{How textbooks perpetuate stereotypes in math: Can't girls do math?}

Figure 2 presents Australian, Singaporean and Turkish textbooks' attitude towards the stereotypes in mathematics. According to the findings, majority of all gender-related items in textbooks across the countries and grade levels did not provide any information about a specific gender doing mathematics.

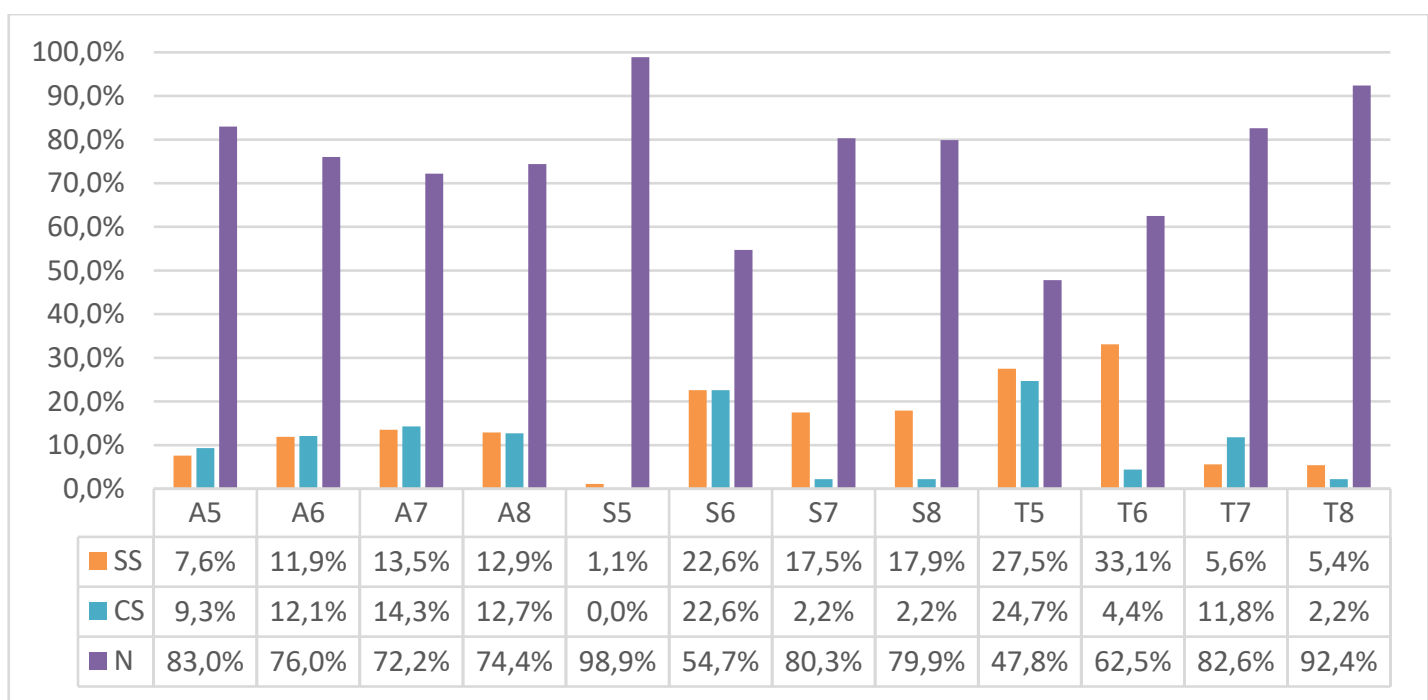

Note: "A" is abbreviation for Australia, "S" is for Singapore and "T" is for Turkey. "SS" is abbreviation for supporting stereotype, "CS" is for counter-stereotype, and " $\mathrm{N}$ " is for neutral.

Figure 2. Stereotype treatment in textbooks 
Except at the 8th grade level, Australian textbooks provided slightly more counter-stereotype cases than those supporting stereotypes. Figure 3 shows some examples from Australian textbooks for their treatment of math stereotypes. Each gender's experiences in mathematics are usually in the form of explanation (or note taking) of some procedures/rules in mathematics (see Figure 3a and Figure 3b). Moreover, as can be seen in Figure 3c, a realistic problem that mentions a female student's use of mathematics in her daily routine is also counted as a counter-stereotype example.

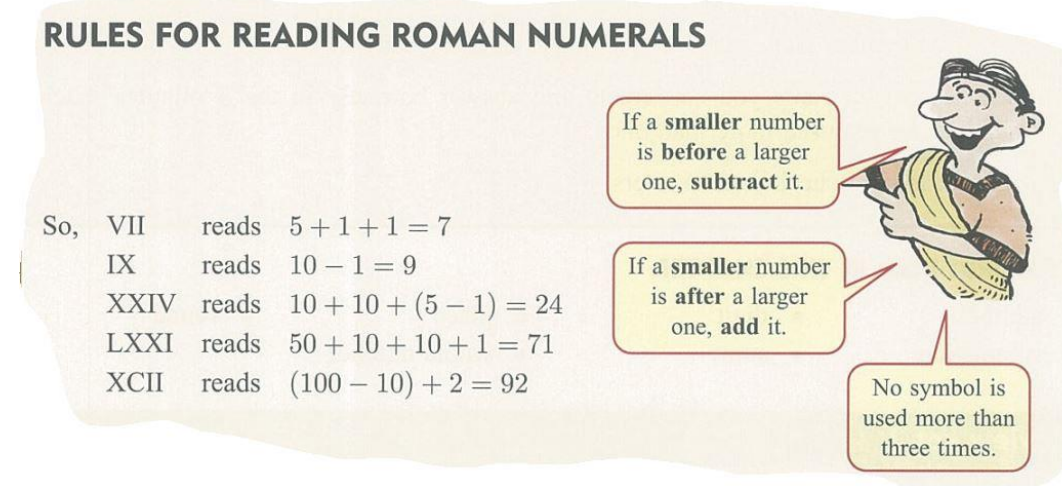

(3a) (A5, p.27)

Imogen kept a record of how much her cat Freckles ate in one week.

She recorded the fraction of a can of food that Freckles ate each day.

a On which day did Freckles eat the most food?

b On which days did Freckles eat the same amounts of food?

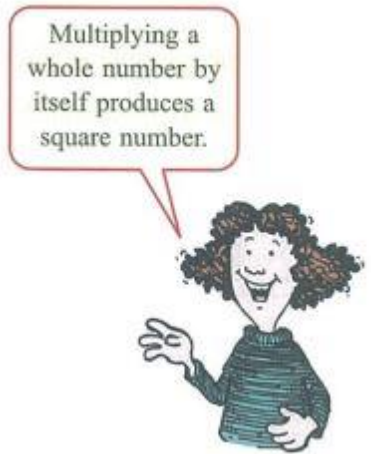

(3b) (A6, p.63)

\begin{tabular}{|c|c|}
\hline Day & Fraction of food \\
\hline Monday & $\frac{2}{3}$ \\
Tuesday & $\frac{3}{9}$ \\
Wednesday & $\frac{5}{6}$ \\
Thursday & $\frac{2}{12}$ \\
Friday & $\frac{4}{6}$ \\
Saturday & $\frac{6}{12}$ \\
Sunday & $\frac{1}{6}$ \\
\hline
\end{tabular}

(3c) (A5, p.106)

Figure 3. Examples for gender stereotype treatment in Australian books

On the other hand, Singaporean textbooks provided more stereotype-favoring examples at all grade levels, especially at the 7th and 8th grade levels. Figure 4a illustrates a math stereotype example that mentions a female student's anxiety of having a good grade in mathematics. Although she was able to calculate the necessary grade for getting a "b" in the course, the message given throughout the story implies a feeling of anxiety instead of self-efficacy in math. On the other hand, Figure 4a demonstrates a male student's capability in math through their use of math skills to solve the problems encountered in daily life in a father-son dialogue. Moreover, story also highlights male-brilliance in math by means of Phytagoreas. 


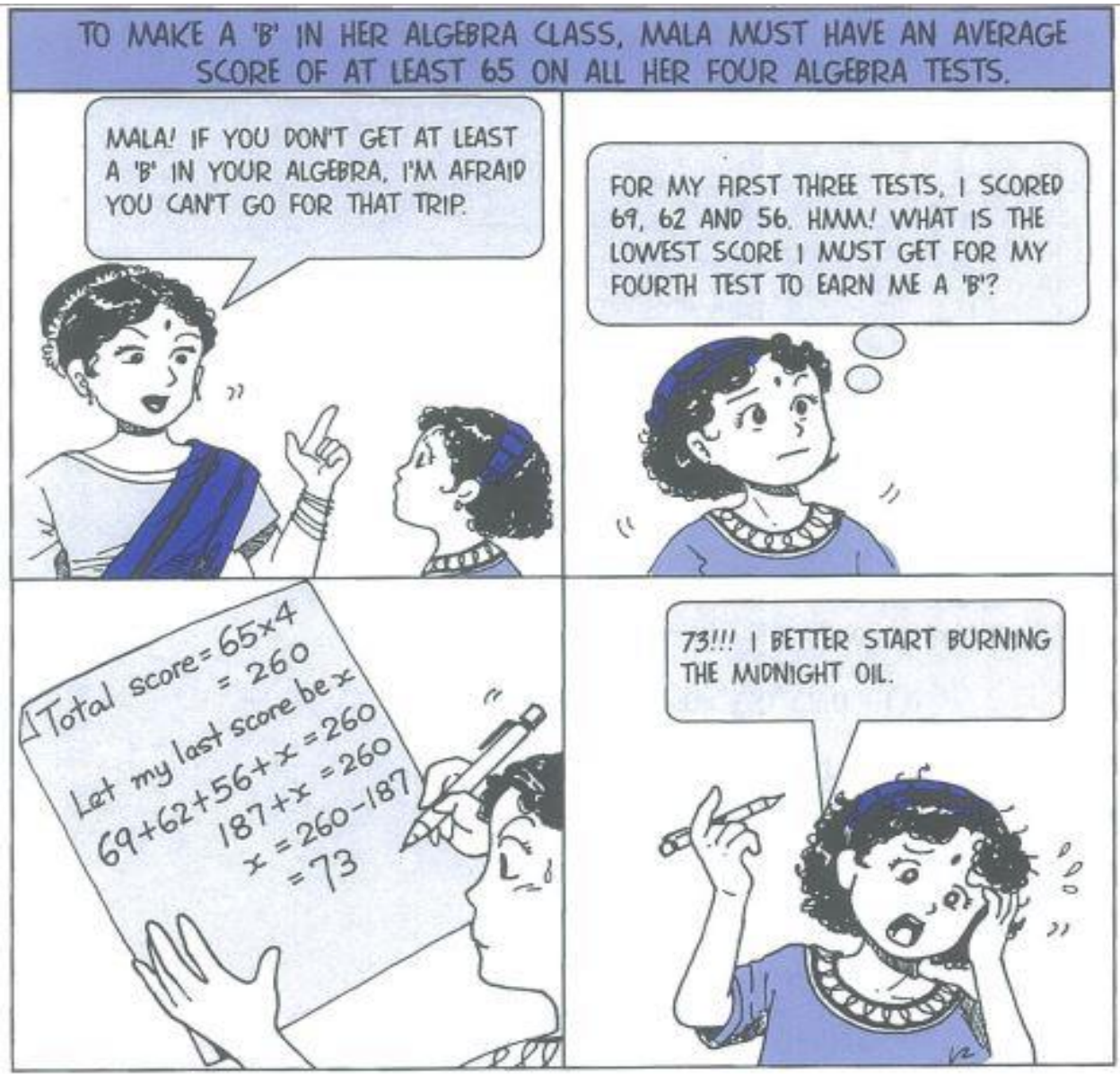

(4a) $($ S7, p.152)

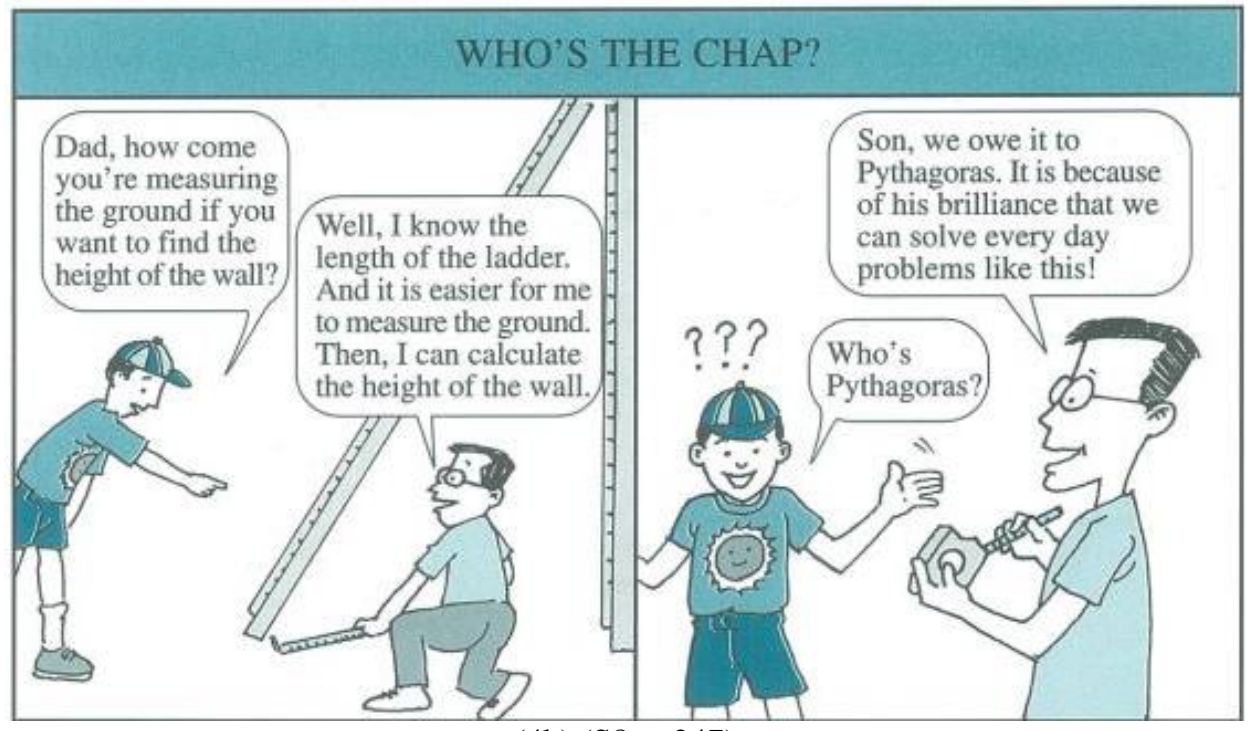

(4b) $(\mathrm{S} 8, \mathrm{p} .247)$

Figure 4. Stereotype-supporting examples in Singaporean math textbooks

Turkish middle school mathematics textbooks, similarly, included more stereotype-supporting examples especially in the 6th grade textbook while 7th grade textbook in Turkey depicted more counterstereotype contents. Figure 5b and Figure 5c illustrate samples that include stereotypes in Turkish textbooks. The former emphasizes men's strengths in mental calculation while the latter provides a male mathematician's (Al Harizm) contribution to math. Figure 5a, on the other hand, indicates that females can perform mathematical operations better than males. 


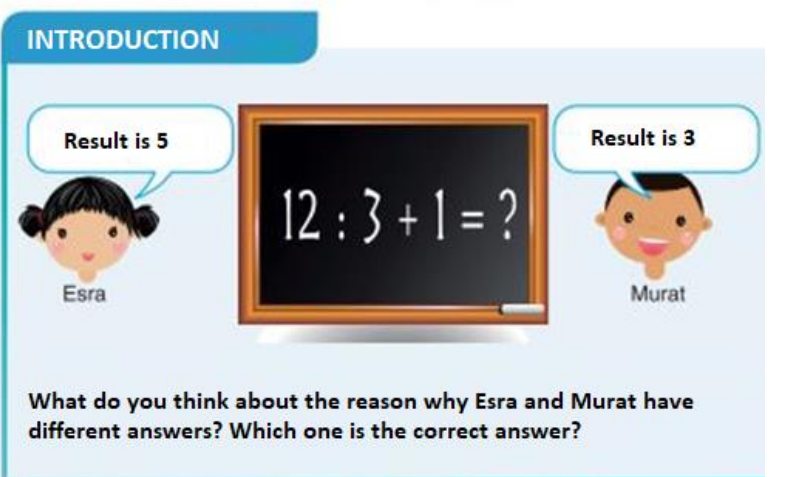

(5a) (T6, p.19)

$$
\begin{aligned}
& 58+10=68 \\
& 68+10=78 \\
& 78+5=83
\end{aligned}
$$

Ali made an addition operation from his mind by following the steps above. Let's find out which two numbers Ali has added.

(5b) (T5, p.42)

\section{Did you know that?}

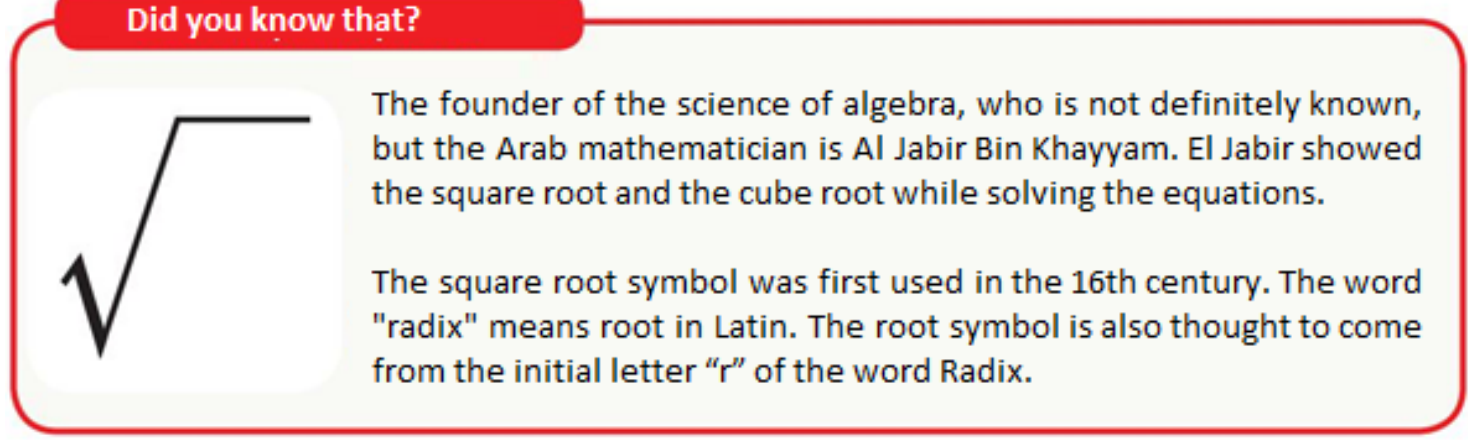

(5c) $(\mathrm{T} 8, \mathrm{p} .49)$

Figure 5. Treatment of stereotypes in Turkish math textbooks

Arab mathematician Al Jabir Bin Khayyam is claimed to be the founder of Algebra science. Al Jabir taught how to calculate the square root and the cube root while solving equations. The square root symbol was first used in the 16th century. The word "radix" means root in Latin. The root symbol is also thought to come from the initial letter " $r$ " of the word Radix.

\section{Gender Stereotypes in Social Roles}

Table 5, shows the distribution of social roles in mathematics textbooks across the countries. According to Table 5, the social roles in the textbooks are more varied for men. In addition, the frequency of social roles for men is also higher in all countries. In all countries, traditional masculine (TM) roles such as constructer, driver, carpenter and plumber are++ mostly depicted as males. However, TM roles such as farmer and craftsman are portrayed as females in Australian textbooks though their frequencies of appearance are very low. Moreover, masculine role of police officer is illustrated as females in Australian textbooks while it is a male role in Turkish math textbooks. Singaporean textbooks have no exhibition of TM roles as females. Similarly, Turkish textbooks also represented TM roles as male with the exception that a doctor is depicted as both male and female. Similar to TM roles, traditional female (TF) roles are also associated with females in most cases. In Australian textbooks, TF roles of housewife and nurse are only depicted as females. Although TF roles of cook, teacher, waiter, house economist and florist are depicted as males, their frequency is low compared to that of females. In Singaporean textbooks, only three TF roles were found out: Cook, teacher, typist. In Australian textbooks, while cooking is mainly depicted as a female role, it is represented as a male role as well. Among the TF roles, teaching is attributed to males while typing is associated with females in Australian textbooks. Turkish textbooks are the only ones that link cooking only with females. Moreover, TF roles of housewife and anchorwoman are also depicted as female roles in textbooks from Turkey while gardening is associated with males. TM role of teacher, represented as male in Singaporean texts, is mostly identified as a female role in Turkish textbooks as well as in Australian textbooks. 
Table 5 .

Social roles in textbooks

\begin{tabular}{|c|c|c|c|c|c|c|}
\hline Roles & Gender & $\begin{array}{c}\text { Male } \\
\text { Traditional }\end{array}$ & $\begin{array}{c}\text { Female } \\
\text { Traditional }\end{array}$ & Other & $\begin{array}{c}\text { Number of } \\
\text { Different Roles }\end{array}$ & $\begin{array}{c}\text { Total } \\
\text { Frequency }\end{array}$ \\
\hline \multirow{23}{*}{ Australia } & \multirow{13}{*}{ Male } & Farmer (15) & Cook (3) & Sportsperson (73) & \multirow{13}{*}{27} & \multirow{13}{*}{213} \\
\hline & & Constructer(9) & Waiter & Shopper (29) & & \\
\hline & & Fisher (5) & Florist & Staff/Worker (19) & & \\
\hline & & Craftsman (3) & H. Economist & Scientist (17) & & \\
\hline & & Pilot (3) & Teacher & Student (8) & & \\
\hline & & Plumber (2) & & Celebrity (8) & & \\
\hline & & Fireman (2) & & Artist (4) & & \\
\hline & & Carp Enter & & Tourist (2) & & \\
\hline & & Architect & & Business Owner & & \\
\hline & & Driver & & & & \\
\hline & & Doctor & & & & \\
\hline & & Dentist & & & & \\
\hline & & Sweeper & & & & \\
\hline & \multirow{10}{*}{ Female } & Farmer (2) & Housewife (9) & Shopper (46) & \multirow{10}{*}{21} & \multirow{10}{*}{144} \\
\hline & & Craftsman & Cook (8) & Sportsperson (28) & & \\
\hline & & Police Officer & H. Economist (4) & Staff/Worker (9) & & \\
\hline & & & Teacher (4) & Student (8) & & \\
\hline & & & Florist (2) & Business Owner (5) & & \\
\hline & & & Nurse (2) & Scientist (4) & & \\
\hline & & & Waiter (2) & Artist (4) & & \\
\hline & & & & Tailor (2) & & \\
\hline & & & & Tourist (2) & & \\
\hline & & & & Celebrity & & \\
\hline \multirow{13}{*}{ Singapore } & \multirow{7}{*}{ Male } & Craftsman (14) & & Staff/Worker (32) & \multirow{7}{*}{16} & \multirow{7}{*}{122} \\
\hline & & Driver (7) & & Sportsperson (27) & & \\
\hline & & Constructer (2) & & Shopper (13) & & \\
\hline & & Doctor & & Business Owner (9) & & \\
\hline & & Captain & & Student (7) & & \\
\hline & & Fisher & & Tourist, Artist & & \\
\hline & & Farmer & & & & \\
\hline & \multirow{6}{*}{ Female } & Cook (3) & Cook (5) & Shopper (13) & \multirow{6}{*}{8} & \multirow{6}{*}{36} \\
\hline & & Teacher (2) & Typist (2) & Student (5) & & \\
\hline & & & & Staff/Worker (4) & & \\
\hline & & & & Sportsperson (3) & & \\
\hline & & & & Tailor (2) & & \\
\hline & & & & Business Owner & & \\
\hline \multirow{21}{*}{ Turkey } & \multirow{11}{*}{ Male } & Constructer (7) & Gardener & Cook (7) & \multirow{11}{*}{23} & \\
\hline & & Farmer (4) & Teacher & Housewife & & \\
\hline & & Craftsman (3) & & Teacher (4) & & \\
\hline & & Manager (2) & & Anchorwoman (2) & & \\
\hline & & Plumber (2) & & & & \\
\hline & & Driver (2) & & & & 207 \\
\hline & & Engineer & & & & \\
\hline & & Architect & & & & \\
\hline & & Fisher & & & & \\
\hline & & Doctor & & & & \\
\hline & & Police Officer & & & & \\
\hline & & Doctor & Student (74) & Student (79) & & \\
\hline & & & Scientist (55) & Shopper (5) & & \\
\hline & & & Staff/Worker (18) & Staff/Worker & & \\
\hline & & & Shopper (14) & Entrepreneur (2) & & \\
\hline & Female & & Sportsperson (12) & Sportsperson (2) & 11 & 104 \\
\hline & Female & & Business Owner (2) & Scientist (2) & 11 & 104 \\
\hline & & & Celebrity (2) & & & \\
\hline & & & Tailor & & & \\
\hline & & & Tourist & & & \\
\hline & & & Artist & & & \\
\hline
\end{tabular}

In Australian textbooks, among the other social roles that are associated with both genders included shopper, sportsperson, staff/worker, student, business owner, scientist, artist, tailor, tourist, and celebrity. However, sportsperson, staff/worker, scientist and celebrity were more frequently mentioned 
as male while shopper and business owner are represented as a female role. Shopper role is equally distributed between both genders in Singaporean textbooks while it is mainly attributed to males in Turkish books. Tailor is a female role in both Singaporean and Australian textbooks while it is depicted as a male role in Turkish textbooks. Although Singaporean textbooks associate both genders with the roles of staff/worker, sportsperson, business owner, and student, these roles more frequently depicted as male roles. Roles of scientist, staff/worker, and sportsperson are mostly associated with males while the role of students is mostly depicted as female in Turkish textbooks. In addition, business owner, celebrity, tourist and artist are among the roles that are only linked with males while the role of entrepreneur is only depicted as female in Turkish textbooks.

\section{DISCUSSION and CONCLUSION}

This cross-national study sheds light on gender bias in Singaporean, Australian and Turkish mathematics textbooks. According to the findings, there is an unbalanced gender representation in all sample mathematics textbooks. Total frequencies in textbook contents including no gender bias are under 9\% for all textbooks. On the other hand, the results indicate that textbooks from all countries have more male contents. More specifically, among the content with both genders, no gender bias is more prevalent across different grade levels in Australian textbooks. Higher frequency of female characters in Australian textbooks implies a message through hidden curriculum in textbooks that they can learn mathematics as well as boys. Except the ones at 8th grade level, Australian textbooks include slightly more counter-stereotype cases than supporting cases, which shows that there is a high level of awareness of the importance of avoiding gender stereotyping in many Australian textbooks. In all sample countries' textbooks, frequencies of male and female characters are close to each other in the 5th grade textbook of each country. However, at the other grade levels, textbooks included more male-related characters, especially in the Singaporean mathematics textbooks at the 7th and 8th grades. Interestingly, Singaporean mathematics textbooks have more discrepancy between the percentages of solely male and solely female representations than the textbooks of other countries. Gender representation in Singaporean textbooks in the current study bears a resemblance to some studies on gender representation in Chinese, Malaysian and Indian textbooks. For example, male appearances have a much higher frequency than female appearances in Chinese textbooks (Tang et al., 2010; Zhang \& Zhou, 2008). Likewise, studies in India show a high rate of male dominancy in the textbook contents (Sumalatha \& Ramakrishnaiah, 2004), and the female share in the picture content is only $35.2 \%$ in Malaysian textbooks (Islam \& Asadullah, 2018). Similarities between the results related to gender representation in Indian, Malaysian and Chinese textbooks and Singaporean textbooks in the current study can be evaluated as an important indicator to consider possible relationships between the ethnic nature of population and gender presentation in textbooks since Chinese, Malays, and Indians make up the majority of ethnic group population in Singapore's population (Trocki, 2006). Among those ethnic groups, the Chinese dominate in Singapore's population (above 70\%). For this reason, any distribution or frequency concerning the role of women in Singapore may have similarities with the one in China. These results showed that developing countries may also include highly unbalanced gender representation just as in the case of underdeveloped countries.

In terms of math-gender stereotypes, all textbooks across grade levels (except the Singaporean 6th grade textbook and Turkish 5th and 6th grade textbooks) have neutral attitude towards the stereotypes in mathematics. That means textbooks across the countries generally do not favored any gender in terms of mathematics ability/capability. Mathematics teaching materials play an important role in providing knowledge and social values. Hidden curriculum in mathematics teaching materials does not have instant, but rather, far-reaching influences on students. Integrating math-gender stereotype materials including textbooks into learning environments has a negative effect on (usually female) students' expected outcomes of mathematics performance (Sekaquaptewa \& Thompson, 2003), their 
mathematical learning ability (Appel, Kronberger, \& Aronson, 2011), the value they place on mathematical success (Eccles, 2011), and even having math-related careers in future (Davies, Spencer, Quinn, \& Gerhardstein, 2002). Therefore, it is significant to having evidence in Turkish, Australian and Singaporean textbooks for practices for gender equity in mathematics teaching materials. Among the countries, Singaporean textbooks include more math-gender stereotype-favoring examples at all grade levels, especially at the 7th and 8th grade levels (e.g., a female's anxiety of having a good grade in mathematics instead of self-efficacy). At this point, a criticism can be made of the idea that negative math-gender stereotypes could be a reason for the constant problems in females' learning and performance of mathematics on standardized tests (Spencer et al., 1999). Singapore had the highest mathematics test scores in 2017 PISA. However, their textbooks include many stereotyping samples. Moreover, Mullis, Martin, Foy and Hooper (2016) noted that there was no statistical difference in girls' and boys' average mathematics achievement scores in Singapore and Turkey in the report of TIMSS International Results of Mathematics. However, the report shows there was statistically significant difference between girls' and boys' average mathematics achievement in Australia in favor of boys. In the presence of such inconsistent statements, we believe that further empirical studies and statistical analysis are necessary to understand the role of math-gender stereotypes on males' and females' mathematics achievement and beliefs.

According to the results, social roles in mathematics textbooks across the countries have more variation for men than for women with higher frequencies in all countries. Interestingly, but perhaps not surprisingly, traditional masculine roles such as carpenter and constructer are depicted as male roles in all countries' textbooks. Some other traditional male roles (e.g., farmer and craftsman) are represented as female roles in Australian textbooks with low frequencies. Such roles are not given in Singaporean and Turkish textbooks. On the other hand, traditional female roles are represented in all textbooks. However, we have observed that textbooks show some roles in different gender representations. For example, the results show that while housewife and nurse are exhibited as traditional female roles in most textbooks, cook, teacher, house economist, and florist are depicted as male roles in Australian textbooks. Another interesting result was found concerning the use of teacher role in textbooks. Although teacher role is depicted as a male role in Singaporean textbooks, it is presented as a female role in both Australian and Turkish textbooks. Similarly, tailor has a female role in both Singaporean and Australian textbooks while it is portrayed as a male in Turkish textbooks. Furthermore, the masculine role commonly shows a more technical and intellectual tendency in the textbooks. However, female roles depicted in textbooks include staying at home and looking after the family, garden or baby. This is a reflection of traditional approach towards gender roles in society (e.g., A man's home is his castle; a woman's place is the home). Nowadays, many women have professional occupations. However, there is still a clear distinction in the perception about male and female professions similar to the idea that males are superior and more competent than their female counterparts in mathematics (Passolunghi et al., 2014; Zhao et al., 2018). For instance, studies indicate that boys are more interested in having math-related careers than girls (e.g. Plante et al., 2009; Shapka et al., 2006). Similarly, while high status occupations like scientist, astronaut, pilot and professor are associated with men, other occupations such as nurse, teacher and secretary are considered as female jobs in textbooks in the current study. Considering the differences in gendered social roles in the textbooks of countries, it may be argued that a person's beliefs in society should be interpreted based on social, cultural and other factors (Lee, 2019; Wu et al., 2016). Some contemporary researchers argue that it is not sufficient to only change the structures of textbooks without understanding the readers' interpretation of textbooks (Lee \& Collins, 2009) or making any reforms that affect society's beliefs and attitudes towards gender. For example, in Africa, teachers believe that boys need career, and girls need husbands (Kabeer, 2005). Additionally, "girls don't do math" is a common cultural stereotype in the United States (Cvencek, Meltzoff, \& Greenwald, 2011). Based on social learning theory, children learn through observation and modelling in a learning environment.

As stated before, exposure to biased contents in textbooks leads to gender stereotyping and negative impacts on learners' personal development (Brugeilles \& Sylvie, 2009; Lee, 2019). As a final point, we also want to share some possible suggestions about how gender-equal mathematics textbooks can be organized for future studies in the light of the results obtained from our cross-national study. In the 
current study, there is unbalanced distribution of gender across grade levels in textbooks. For this reason, depicting male and female characters within a balanced frequency in texts and images may be the first step to promote gender equity in textbooks. Another approach can be equal distribution of social roles to males and females without traditional perceptions about the careers concerning science, engineering, technology and mathematics. For example, Wu et al. (2016) suggest that some traditional masculine roles associated with females are encouraged in the textbooks at higher grade levels, which can potentially support girls' mathematical confidence and self-efficacy. In the current study, we mainly explore messages implying gender equity within elementary mathematics textbooks via a cross-national study. However, we believe that learners' reactions to gender representation in textbooks are not observed and interpreted directly due to implicit nature of hidden curriculum materials. Additionally, there is interaction between textbook and teacher during the instruction. Teachers' tendency and treatments of traditional gender roles gain importance to understand the influence of textbooks on gender bias. Future research can investigate teachers' treatment of gendered materials in classrooms in addition to the present textbook analysis. For this reason, classroom observations may be conducted to understand how teachers use gender messages while teaching when they use compulsory textbooks or other curriculum resources. In conclusion, teaching materials cannot be considered without such factors as culture, society and history (Wu et al., 2016). These factors with a long history do not allow a change in gender bias in a short time. We think that long-term and versatile studies are necessary to eliminate gender stereotypes from textbooks.

\section{REFERENCES}

Appel, M., Kronberger, N., \& Aronson, J. (2011). Stereotype threat impairs ability building: Effects on test preparation among women in science and technology. European Journal of Social Psychology, 41(7), 904913.

Bae, Y., Choy, S., Geddes, C., Sable, J., \& Snyder, T. (2000). Trends in Educational Equity of Girls and Women. Washington, DC: U.S. Government Printing Office.

Bag, E., \& Bayyurt, Y. (2015). Gender representations in EFL textbooks in Turkey, In S. Mills, \& A. S. Mustapha. (Eds.), Gender Representation in Learning Materials: International Perspectives (pp. 64-85), New York: Routledge.

Baldwin, P., \& Baldwin, D. (1992). The portrayal of women in classroom textbooks. Canadian Social Studies, 26(3), 110-114.

Bieg, M., Goetz, T., Wolter, I., \& Hall, N. C. (2015). Gender stereotype endorsement differentially predicts girls' and boys' trait-state discrepancy in math anxiety. Frontiers in Psychology, 6, 1404. DOI: 10.3389/fpsyg.2015.01404

Biemmi, I. (2015). Gender in schools and culture: Taking stock of education in Italy. Gender and Education, 27(7), 812-827. DOI: 10.1080/09540253.2015.1103841

Blumberg, R. L. (2007). Gender Bias in Textbooks: A Hidden Obstacle on the Road to Gender Equality in Education. Paris: UNESCO.

Blumberg, R. L. (2008). The invisible obstacle to educational equality: Gender bias in textbooks. Prospects, 38(3), 345-361. DOI: 10.1007/s11125-009-9086-1

Britton, G. E., \& Lumpkin, M.C. (1977). For sale: Subliminal bias in textbooks. The Reading Teacher, 31(1), 4045.

Brugeilles, C., \& Sylvie. C. (2009). Promoting Gender Equality Through Textbook. A Methodological Guide. Paris: UNESCO.

Chanzanagh, H. E., Esmaeelzadeh, Z., \& Zarsazkar, M. (2011). Gender in school: A case-study on Iran's primary levels-school subjects. Procedia Social and Behavioral Sciences, 15(2011), 1832-1838. DOI: 10.1016/j.sbspro.2011.04.011

Chisamya, G., DeJaeghere, J., Kendall, N., \& Khan, M. A. (2012). Gender and education for all: Progress and problems in achieving gender equity. International Journal of Educational Development, 32(6), 743-755. DOI: 10.1016/j.ijedudev.2011.10.004

Cincotta, M. S. (1978). Textbooks and their influence on sex-role stereotype formation. Babel: Journal of the Australian Federation of Modern Language Teacher's Association, 14(3), 24-29.

Cohen, L., Manion, L., \& Morrison, K. (1994). Educational Research Methodology. Athens: Metaixmio. 
Correll, S. J. (2001). Gender and the career choice process: The role of biased self-assessments. American Journal of Sociology, 106(6), 1691-1730. DOI: 10.1086/321299

Crabb, P. B., \& Bielawski, D. (1994). The social representation of material culture and gender in children's books. Sex Roles, 30(1-2), 69-79. DOI: 10.1007/BF01420740

Cvencek, D., Meltzoff, A. N., \& Greenwald, A. G. (2011). Math-gender stereotypes in elementary school children. Child Development, 82(3), 766-779. DOI: 10.1111/j.1467-8624.2010.01529.x

Davies, P. G., Spencer, S. J., Quinn, D. M., \& Gerhardstein, R. (2002). Consuming images: How television commercials that elicit stereotype threat can restrain women academically and professionally. Personality and Social Psychology Bulletin, 28, 1615-1628.

Doyle, R. A., \& Voyer, D. (2016). Stereotype manipulation effects on math and spatial test performance: A metaanalysis. Learning and Individual Differences, 47, 103-116. DOI: 10.1016/j.lindif.2015.12.018

Eccles, J. (2011). Gendered educational and occupational choices: Applying the Eccles et al. model of achievement-related choices. International Journal of Behavioral Development, 35(3), 195-201.

Fan, L., Zhu, Y., \& Miao, Z. (2013). Textbook research in mathematics education: development status and directions. ZDM, 45(5), 633-646. DOI: 10.1007/s11858-013-0539-x

Franceschini, G., Galli, S., Chiesi, F., \& Primi, C. (2014). Implicit gender-math stereotype and women's susceptibility to stereotype threat and stereotype lift. Learning and Individual Differences, 32, $273-277$. DOI: 10.1016/j.lindif.2014.03.020

Good, C., Rattan, A., \& Dweck, C. S. (2012). Why do women opt out? Sense of belonging and women's representation in mathematics. Journal of Personality and Social Psychology, 102(4), 700-717.

Hanna, G. (2000). Declining gender differences from FIMS to TIMSS. Zentralblatt fur Didaktik der Mathematik, 32(1), 11-17. DOI: 10.1007/BF02652734

Hartman, P. L., \& Judd, E. L. (1978). Sexism and TESOL Materials. TESOL Quarterly, 12(4), 383-393.

Heyman, G. D., \& Legare, C. H. (2004). Children's beliefs about gender differences in the academic and social domains. Sex Roles, 50, 227-239. DOI: 10.1023/B:SERS.0000015554.12336.30

Islam, K., \& Asadullah, M. N. (2018). Gender stereotypes and education: A comparative content analysis of Malaysian, Indonesian, Pakistani and Bangladeshi school textbooks. PLoS ONE, 13(1): e0190807. DOI: 10.1371/journal. pone.0190807

Kabeer N. (2005). Gender equality and women's empowerment: A critical analysis of the third millennium development goal. Gender and Development, 13(1), 13-24. DOI: 10.1080/13552070512331332273

Kurtz-Costes, B., Rowley, S. J., Harris-Britt, A., \& Woods, T. A. (2008). Gender stereotypes about mathematics and science and self-perceptions of ability in late childhood and early adolescence. Merrill-Palmer Quarterly, 54(3), 386-409.

Lee, J. F. K. (2019). In the pursuit of a gender-equal society: Do Japanese EFL textbooks play a role?. Journal of Gender Studies, 28(2), 204-217. DOI: 10.1080/09589236.2018.1423956

Lee, J. F. K., \& Collins, P. (2009). Australian English language textbooks: The gender issues. Gender and Education, 21(4), 353-370. DOI: 10.1080/09540250802392257

Lindberg, S., Linkersdörfer, J., Ehm, J., Hasselhorn, M., \& Lonnemann, J. (2013). Gender differences in children's math self-concept in the first years of elementary school. Journal of Education and Learning, 2(3), 1-8. DOI: $10.5539 /$ jel.v2n3p1

Luyt, B., Lee, S. S., \& Yong, N. Y. (2011). Gender representations and stereotypes in Singaporean picture books: 1970 to 2008. Malaysian Journal of Library and Information Science, 16(3), 49-65.

Martinot, D., \& Désert, M. (2007). Awareness of a gender stereotype, personal beliefs and self-perceptions regarding math ability: When boys do not surpass girls. Social Psychology of Education, 10(4), 455-471. DOI: $10.1007 / \mathrm{s} 11218-007-9028-9$

Ministry of Education Singapore (2019). Approved textbook list. Retrieved October 23, 2019, from https://www.moe.gov.sg/education/syllabuses/approved-textbook-list.

Mullis, I. V., Martin, M. O., Foy, P., \& Hooper, M. (2016). TIMSS 2015 International Results in Mathematics. Boston College: TIMSS \& PIRLS International Study Center.

Murphy, P. F., \& Gipps, C. V. (1996). Equity in the Classroom. London: Falmer Press

Muzzatti, B., \& Agnoli, F. (2007). Gender and mathematics: Attitudes and stereotype threat susceptibility in Italian children. Developmental Psychology, 43(3), 747-759. DOI: 10.1037/0012-1649.43.3.747

Nicol, C. C., \& Crespo, S. M. (2006). Learning to teach with mathematics textbooks: How preservice teachers interpret and use curriculum materials. Educational Studies in Mathematics, 62(3), 331-355. DOI: 10.1007/s10649-006-5423-y

Passolunghi, M. C., Rueda-Ferreira, T. I. R., \& Tomasetto, C. (2014). Math-gender stereotypes and math-related beliefs in childhood and early adolescence. Learning and Individual Differences, 34, 70-76. DOI: 10.1016/j.lindif.2014.05.005 
Pepin, B., \& Haggarty, L. (2001). Mathematics textbooks and their use in English, French and German classrooms: A way to understand teaching and learning cultures. ZDM: International Journal on Mathematics Education, 33(5), 158-175. DOI: 10.1007/BF02656616

Peterson, S. B., \& Lach, M. A. (1990). Gender stereotypes in children's books: Their prevalence and influence on cognitive and affective development. Gender and Education, 2(2), 185-197. DOI: 10.1080/0954025900020204

Plante, I., Theoret, M., \& Favreau, O. E. (2009). Student gender stereotypes: Contrasting the perceived maleness and femaleness of mathematics and language. Educational Psychology, 29(4), 385-405. DOI: $10.1080 / 01443410902971500$

Quinn, D. M., \& Spencer, S. J. (2001). The interference of stereotype threat with women's generation of mathematics problem-solving strategies. Journal of Social Issues, 57(1), 55-71. DOI: 10.1111/00224537.00201

Remillard J. T. (2005). Examining key concepts in research on teachers' use of mathematics curricula. Review of Educational Research, 75(2), 211-246. DOI: 10.3102/00346543075002211

Schmader, T., Johns, M., \& Barquissau, M. (2004). The costs of accepting gender differences: The role of stereotype endorsement in women's experience in the math domain. Sex Roles, 50(11-12), 835-850. DOI: 10.1023/B:SERS.0000029101.74557.a0

Sekaquaptewa, D., \& Thompson, M. (2003). Solo status, stereotype threat, and performance expectancies: Their effects on women's performance. Journal of Experimental Social Psychology, 39(1), 68-74.

Shapka, J. D., Domene, J. F., \& Keating, D. P. (2006). Trajectories of career aspirations through adolescence and young adulthood: Early math achievement as a critical filter. Educational Research and Evaluation, 12(4), 347-358. DOI: 10.1080/13803610600765752

Sherman, J. A. (1982). Mathematics as a critical filter: A look at some residues. Psychology of Women Quarterly, $6(4), 428-444$.

Shi, J. X. (2004). Exploring the Gender World of Textbooks and Teaching Process. Beijing: Educational Science Press.

Spencer, S. J., Steele, C. M., \& Quinn, D. M. (1999). Stereotype threat and women's math performance. Journal of Experimental Social Psychology, 35(1), 4-28. DOI: 10.1006/jesp.1998.1373

Steffens, M. C., Jelenec, P., \& Noack, P. (2010). On the leaky math pipeline: Comparing implicit math-gender stereotypes and math withdrawal in female and male children and adolescents. Journal of Educational Psychology, 102(4), 947-963.

Sumalatha, K., \& Ramakrishnaiah, D. (2004). Sex bias in secondary school social studies textbooks: A case study in India. American Journal of Applied Science, 1, 62-63.

Tang, H., Chen, B., \& Zhang, W. (2010). Gender issues in mathematical textbooks of primary schools. Journal of Mathematics Education, 3(2), 106-114.

Tine, M., \& Gotlieb, R. (2013). Gender, race, and income-based stereotype threat: The effects of multiple stigmatized aspects of identity on math performance and working memory function. Social Psychology of Education, 16(3), 353-376. DOI: 10.1007/s11218-013-9224-8

Trocki, C. (2006). Singapore: Wealth, Power and the Culture of Control. London: Routledge.

Ullah, H., Abdullah, F., Ahmad, A., \& Ali, R. (2017). Gender representations in mathematics textbooks in AzadJammu and Kashmir. International Journal of Innovation in Teaching and Learning, 3(2), 1-17.

Wu, Y., Widjaja, W., \& Li, J. (2016). Gender issues in elementary mathematics teaching materials. In Liyanage I., \& Nima B. (Eds.) Multidisciplinary Research Perspectives in Education. Sense Publishers: Rotterdam. DOI: 10.1163/9789463006156_019

Zakka, Z. M., Oluyemi, S., \& Twaki, G. (2015). Analyzing Gender representation in primary 5 and 6 mathematics textbooks in Nigeria. International Journal of Educational Studies, 2(2), 109-114.

Zhang, X., \& Zhou, H. M. (2008). Analyzing gender stereotypes within primary mathematics textbooks. Education Research Monthly, 7, 23-25.

Zhang, Y., Kao, G., \& Hannum, E. (2007). Do mothers in rural China practice gender equality in educational aspirations for their children?. Comparative Education Review, 51(2), 131-157. DOI: 10.1086/512023

Zhao, F., Zhang, Y., Alterman, V., Zhang, B., \& Yu, G. (2018). Can math-gender stereotypes be reduced? A theory-based intervention program with adolescent girls. Current Psychology, 37(3), 612-624. DOI: 10.1007/s12144-016-9543-y 


\section{TÜRKÇE GENIŞLETILMIŞ ÖZET}

Eğitim eşitliğine göre kız ve erkek çocukların eğitimsel olanaklara erişimlerinde eşitlik olması gerekmektedir (Bae vd., 2000). Fakat yıllardır yapılan çalışmaların vurguladığı önemli bir konu, okullarda erkeklerin kızlara oranla daha yetenekli ve üstün olduğuna dair cinsiyet vurgularının ve basmakalıp söylemlerin varlığıdır (Blumberg, 2007; Chisamya vd., 2012). Eğitim süreçlerinin önemli bir bileşeni olan ders kitapları cinsiyet vurgularında denge yaratma konusunda önemli bir role sahiptir (Baldwin ve Baldwin, 1992; Biemmi, 2015; Blumberg, 2009). Yapılan birçok çalışma, ders kitaplarının cinsiyet bakımından dengeli ve adil hazırlanmasının kız öğrencilerin matematiğe karşı tutumunu ve kariyer tercihlerini etkilediğine vurgu yapmaktadır (Britton ve Lumpkin, 1977; Wu vd., 2016). Öğrenme konuları içinde, matematik uzun yılardan beri kitaplar ve öğretim materyallerine dayalı olarak öğretilen bir derstir (Remillard, 2005). Günümüzde de ders kitapları matematik öğretim sürecinde öğretmenler için önemli bir kaynaktır (Nicol ve Crespo, 2006). Matematik her ne kadar kültürel bileşenlerden etkilenmeyen bir bilim gibi görülse de kitapları yazarları kendi kişisel algılarını ve toplumsal ve kültürel bileşenleri kitap içeriklerine yansıtabilirler (Shi, 2004; Tang vd., 2010). Bu nedenle, ders kitapları içerikleri ve tasarımlarında cinsiyet eşitliğinin yansıtılması gereken önemli bir öğretim materyalidir. Fakat yapılan birçok çalışma, kitap içeriklerinde kızların matematiği erkekler gibi bilemeyeceği/yapamayacağ 1 vurgusuyla ve sosyal roller bakımından kadınlar için daha az entelektüel ve domestik rollerle donatıldığını ortaya çıkarmıştır (Islam ve Asadullah, 2018; Tang vd., 2010; Ullah vd., 2017). Diğer taraftan, Fan ve diğerleri (2013) matematik ders kitaplarında cinsiyet bakımında dengeli bir yapı sunmanın kitapların tasarımı ve kullanımı bakımından önemli olmasına rağmen kitaplarda cinsiyet ile ilgili konularla ilgili çalışmaların sayıca az olduğuna vurgu yapmaktadır. Ayrıca araştırmacılar bu konuda yapılacak çalışmaların ders kitap yazarları ve öğretim programı tasarımcıları açısından kritik olduğunu vurgulamaktadır. Benzer şekilde, Blumberg (2007) kitaplardaki basmakalıp cinsiyet eğilimlerinin cinsiyet eşitliği yolunda bir engel teşkil ettiğini belirtmektedir. Yapılan çok sayıda uluslararası çalışmanın vurguladığı diğer önemli bir konu da çocukların matematik ile ilgili cinsiyetçi basmakalıp imajlarının ortaokul düzeyinde şekillendiğidir. Bu yönüyle, ders kitaplarındaki matematik ile ilgili cinsiyetçi basmakalıplar ortaokul düzeyinde kız çocuklarının matematik başarısı ve kariyer tercihleri açısından potansiyel bir tehdit unsuru sayılmaktadır (Zhao vd., 2018). Bu nedenle, bu araştırma Avustralya, Singapur ve Türkiye ortaokul matematik ders kitaplarında cinsiyet faktörlerinin nasıl ele alındığını incelemeyi amaçlamıştır. Bu amaç doğrultusunda şu iki soruya cevap aranmıştır:

Avustralya, Singapur ve Türkiye ortaokul matematik ders kitaplarındaki cinsiyet içerikleri dağılımı nasıldır? Kitaplarda matematik ve toplumsal roller bakımından sunulan cinsiyet basmakalıpları nelerdir ve nasıl dağılmaktadır?

Bu üç ülkenin kitapları belli ölçütler referans alınarak belirlenmiştir. Bunlar; (i) 2017 Küresel Cinsiyet Açığı Endeksi, (ii) PISA-2015 matematik başarı ortalamaları ve (iii) ülkelerin okuryazarlık oranlarıdır (Bkz. Tablo/Table 1). Ülkeler içinde Singapur, PISA matematik başarı ortalaması en yükssek olanıyken, Türkiye matematik başarı ortalaması diğer iki ülkeye göre en düşük olanıdır. Cinsiyet eşitliği paritesi iki ülkeye göre yüksek olan ülke ise Avustralya olarak görülmektedir. Bu araştırmada edinilecek sonuçlarının ülkelerin kitaplardaki cinsiyet faktörleri ile ülkelerin uluslararası sınav başarıların ve cinsiyet eşitlik ilişkilerinin yorumlamasına da önemli katkılar sunacağı düşünülmektedir.

Araştırmada ortaokul matematik ders kitapları doküman analizine göre incelenmiştir. Tüm kitaplar cinsiyet bileşenleri doğrultusunda belirlenen kategorilerde içerik analizine tabii tutulmuştur. Kitaplar amaçlı örneklem seçimine göre belirlenmiştir. Türkiye ve Singapur, matematik derslerinde Milli Eğitim Bakanlığ 1 tarafından hazırlanan ve standartlaştırılmış ders kitapları kullanmaktadır. Avustralya'da ise yaygın kullanılan kitaplar mevcuttur. Çalışmada hangi yayınevine ait kitapların kullanıldı̆̆ 1 Tablo 2'de (Table 2) sunulmuştur. Tüm matematik ders kitaplarındaki görsel elemanlar ve senaryo/problem 
içerikleri 5-8 sınıf seviyesinde ayrı ayrı ülkelere göre sayısal olarak hesaplanmıştır (Bkz. Tablo/Table 3). İlk araştırma sorusuna cevap vermek için kitaplardaki görseller ve yazılı içerikler ve problemlerde kullanılan isimler cinsiyet vurgusu bakımından incelenmiştir. Cinsiyetteki baskınlığa göre (i) kadınbaskın ve (ii) erkek-baskın olarak kodlanmıştır. Eğer cinsiyet, incelenen içerikte net değilse "cinsiyet eğilimi yok" olarak kodlanmıştır. Diğer taraftan, cinsiyet açısından matematik içerikli basmakalıp analizi (ör. kadınlar matematik öğrenemez/yapamaz veya erkekler matematikte daha başarılıdır.) de üç grupta ele alınmıştır: (i) basmakalıp karşıtı (ii) basmakalıp destekleyici ve (iii) nötr kullanım. Örneğin, kitapta bir kadın/kız çocuk problem çözüyorsa ve matematik yapma veya kullanmaya dair cinsiyet bakımından olumlu vurgu varsa bu durum basmakalıp karşıtı kodu ile ele alınmıştır. Diğer taraftan, erkekleri matematikte üstün tutan ve kadınları matematik bağlamında başarısız gösteren kullanımlar ise basmakalıp destekleyici olarak kodlanmıştır. İçerikte herhangi bir cinsiyete matematiksel yapma açısından vurgu yapılmamışsa içerik nötr kullanım olarak kodlanmıştır. Son olarak, kitaplarda bireylere verilen toplumsal rollerin cinsiyetlere göre dağılımları incelenmiştir. Toplumsal rollerin baskınlığ 1 ve dağılımları tüm ülkelerin kitaplarında sınıf düzeylerine göre geleneksel eril roller ve geleneksel dişil roller olarak iki grupta analiz edilmiştir. Rol kodlamasında alan yazına dayanarak, geleneksel eril roller genel olarak erkekler için yansıtılan entelektüel içerikli (ör. Mühendis, avukat, doktor) ve beceri-teknik bilgi odaklı (ör. Su tesisatçısı, marangoz) rollerden oluşmuştur. Geleneksel dişil roller ise daha çok aileev ile ilgili (domestik) ve daha az entelektüel beceri gerektiren rollerden (ör. Bebek bakıcısı, aşçı, çiçekçi, ev hanımı) oluşmuştur.

Araştırma sonuçları, tüm ülkelerde beşinci sınıf düzeyindeki matematik kitaplarında kadın ve erkek gösterimlerinin dağılımının birbirine yakın oranlarda olduğunu göstermiştir. Fakat diğer sınıf düzeylerinde erkek baskın cinsiyet temsil örneği olduğu tespit edilmiştir. Özellikle de Singapur'un yedinci ve sekizinci sınıf ders kitaplarında kadın ve erkek içerikleri arasındaki oran farkı diğer iki ülkeye göre daha fazla bulunmuştur. Singapur kitaplarındaki oransal farkın yüksekliği Çin, Malezya ve/veya Hindistan matematik kitaplarını referans alarak yapılan çalışmaların sonuçlarıyla büyük benzerlik taşımıştır (Islam ve Asadullah, 2018; Sumalatha ve Ramakrishnaiah, 2004; Tang vd., 2010; Zhang ve Zhou, 2008). Bu durum, Singapur halkının çoğunlukla Çin, Malezya ve Hindistan menşeili insanlardan oluşması ile ilgili olabilir (Trocki, 2006).

Matematik ile ilgili cinsiyet basmakalıplar incelendiğinde Singapur altıncı sınıf ve Türkiye beşinci ve altıncı sınıf matematik kitapları hariç tüm kitapların matematik ile ilgili cinsiyet kalıpları konusunda nötr olduğu tespit edilmiştir. Özel olarak, sekizinci sınıf düzeyi hariç Avustralya kitaplarında basmakalıp karşıtı örneklerin diğer ülke kitaplarına göre daha yoğun olduğu ortaya çıkmıştır. Singapur kitaplarında ise basmakalıp destekleyici unsurun yoğun olduğu tespit edilmiştir. Bazı görsellerde kadınların matematik yapma konusunda endişe duyduklarını vurgulayan içeriklere rastlanırken, erkeklerin matematik konusunda başarısını vurgulayan içeriklere rastlanmıştır (Bkz. Şekil/Figure 4-b). Ayrıca çalışma sonuçları, Türkiye kitaplarında ise altıncı sınıfta basmakalıp destekleyici unsur fazlayken yedinci sınıf kitabında basmakalıp karşıtı örneklerin yoğun olduğu dikkat çekmiştir. Ulaşılan bu sonuçlar, matematik ile ilgili basmakalıp cinsiyetçi kullanımların kızların uluslararası sınav başarısı üzerindeki kalıcı etkilerinin yansıtıldığı çalışma sonuçlarıyla (ör. Spencer vd., 1999) farklılıklar taşıdığını göstermiştir. Çünkü matematik ile ilgili basmakalıp cinsiyetçi yaklaşımlar Singapur kitaplarında fazla olmasına rağmen Singapur PISA matematik başarısında en yüksek sonuçları elde etmektedir. Türkiye ise PISA matematik başarı sıralamasında ortalamanın oldukça aşağısında bir sırada kendine yer bulabilmiştir. Sonuçlardaki bu farklılıklar, kitaplardaki cinsiyet içerikleri ve çocukların uluslararası sınav başarıları arasındaki ilişkilerin daha sistematik çalışmalarla araştırılmasının gerekliliğini ortaya çıkarmıştır.

Ülkeler arası toplumsal rollerin matematik kitaplarındaki dağılımları incelendiğinde erkekler için belirtilen rollerin kadınlar için belirtilen rollerden sayıca fazla olduğu görülmüştür (Bkz. Tablo/Table 5). Tüm kitaplarda geleneksel eril rollerin (ör. sürücü, marangoz, su tesisatçısı) erkekler için yansıtıldığ1 dikkat çekmiştir. Fakat Avustralya kitaplarında çiftçi ve zanaatkâr gibi geleneksel eril roller kadınlar için sunulurken, aş̧̧1lık, öğretmenlik ve çiçekçilik gibi rollerin de erkekler için sunulduğu tespit edilmiştir. Diğer taraftan, kitaplarda ev hanımı ve hemşire gibi geleneksel dişil rollerin kadınlar için 
kullanıldığ dikkat çekmiştir. Bu durum aslında toplumdaki cinsiyet rollerinin geleneksel bir yansıması olarak görülebilir. Öğretmenlik mesleği ise Singapur kitaplarında erkekler için resmedilen toplumsal cinsiyet rolüyken, Türkiye ve Avustralya kitaplarında genelde kadınlar için kullanılmıştır. Avustralya kitaplarında ise aşçılık, bahçıvan gibi rollerin de kadınlar için kullanıldığı tespit edilmiştir. Rollerdeki bu farklılaşmalar esasında toplumların kültürel, sosyal ve diğer birçok yapısıyla ilişkili olabilir (Lee, 2019; Wu vd., 2016). Bu konuda birçok çalışma sadece kitapların içerik ve görünüm olarak cinsiyet bağlamında revize edilmesinin cinsiyetçi basmakalıp yaklaşımların, tutumların ve inanışların üstesinden gelmede yeterli olmayacağını vurgulamaktadır (Lee ve Collins, 2009). Bu araştırma sonuçları da gerek ülkelerin uluslararası sınav başarıları, gerek kitaplarda yansıtılan cinsiyet içerikleri bakımından bu görüşü destekler nitelikte olmuştur. Örneğin, Afrika' da "erkekler kariyere kızlar ise kocaya ihtiyaç duyar" anlayışı mevcutken (Kabeer, 2005), Amerika' da "kızlar matematik yapamaz" anlayışı mevcuttur (Cvencek vd., 2011). Bu nedenle, cinsiyet ile ilgili yapılacak reformlar toplumsal ve kültürel değerlerden ayrı tutulamaz. Bu konuda kitap içeriklerinin cinsiyet dağılımı ve toplumsal roller bakımından dengeli şekilde düzenlemesiyle birlikte asıl önemli konulardan biri kitapları kullanan öğretmenlerin derslerdeki yaklaşımıdır. Bu bakımdan, gelecek çalışmalarda öğretmenlerin kitap içeriklerini cinsiyet bağlamında nasıl yansıttıkları incelemek alana önemli katkılar sunabilir. 